\title{
The Impact of Adhesive Percentage Variation on Combustion Value of Durian Skin Biomass Waste
}

\author{
Sahala Siallagan $^{1 *}$, Indra Koto ${ }^{1}$ \\ \{*sahalaal12002@yahoo.com \} \\ Department of Mechanical Engineering, Universitas Negeri Medan, Indonesia ${ }^{1}$
}

\begin{abstract}
Development of Medan has an impact on the waste problem with durian skin significantly and certainly needs to resolve immediately. Innovation by technology development is used to process organic waste to become briquette is one of the ways to solve the waste problem with advantage economically as well as reducing unemployement. The technology built is durian skin chopper, rotary bio carbon machine and briquette press with pneumatic system and amount of tapioca adhesive in order to get effective burning promptness $(\mathrm{gr} / \mathrm{s})$. Briquette is made by mixing tapioca adhesive respectively $6 \%, 9 \%, 12 \%$ and $15 \%$ on durin skin biomass carbon in order to get maximum combustion rate $(\mathrm{gr} / \mathrm{s})$. The highest combustion rate is $5915 \mathrm{cal} / \mathrm{gr}$ (carbon powder is $34 \mathrm{gr}$ and adhesive $6 \%$ ) and the lowest combustion rate is $5611 \mathrm{cal} / \mathrm{gr}$ (carbon powder is $34 \mathrm{gr}$ and adhesive $14 \%$ ). The lowest adhesive value of variation is $6 \%$ with combustion rate is $0.2616 \mathrm{gr} / \mathrm{menit}$ while the highest adhesive value is $15 \%$ with combustion rate is $0.27744 \mathrm{gr} /$ menit. The adhesive containing water will impact on combustion rate.
\end{abstract}

Keywords: Briquette, durian skin, adhesive, combustion value

\section{Introduction}

The increased consumption of oil and gas has impact on the increased price because both fuels are most used compared to the other fuel. The new sources are sought continuously. Biomass waste for example, is processed to be energy. It is suitable in Indonesia especially in North Sumatera bacause it is abundant as waste. Medan, capital of North Sumatera is the third biggest in Indonesia and also industrial and educational city. The growth of Medan has an impact on waste case, such as: durian skin. There are a lot of durian fruits since the durian is icon of Medan tourism. The durian skin waste should be managed promptly, otherwise it will cause environmental pollution and city aesthetics problem. Indonesia produces garbage waste 22.5 million ton and it is predicted to be increased up to 53.7 million ton in 2014 and 50.45 million ton in 2017 [1].

Overcoming waste problem (durian skin and sawdust) is processed to be new sources by means of a simple technology. Durian skin chopper, rotary bio carbon machine and briquette press with pneumatic system are built to process the waste to be briquette. The durian skin waste is mixed with amount of tapioca adhesive in order to get better combustion value. To optimize the combustion value of the briquette as good as LPG or kerosene, tapioca adhesive is added in variety amount. The durian skin contains $50-60 \%$ cellulose, $5 \%$ lignin and $5 \%$ 
low starch. The durian skin contains high carbon and possible to make active carbon to use as adsorbent.

Biocarbon raw material is mashed up to 60 mesh $(0.250 \mathrm{~mm})$. The higher mesh value, the more solid briquette. Briquette adhesive uses tapioca $6 \%, 9 \%, 12 \%$ and $15 \%$ of carbon by using pressure. After mixing the materials are pressured in order to get solid material. [2] implies that adhesive addition will significantly impact on briquette's characteristics, such as: density, ash and water content. The more adhesive, it will get better density, pressure and more ash and water except for heating value will be inversely proportional.

\section{Methodology}

Fuel is material which can be changed to be energy. Normally fuel contains calorie of heat that can be manipulated. Mostly the fuel used by human being is the fuel which the combustion reacted with oxygen.

The combustion is a chemical reaction of fuel and oxidation that can produce heat and light. The combustion can be burn out if there is [4]:

a. Fuel

b. Oxidation / air

c. Heat

Calorie value of fuel analysis in order to get data of calorie of heat produced by combustion process [3]. The good quality briquette has a smooth texture, tough, environmentally friendly, inflammable, long lasting combustion, no smoke black and high heating value. The longer flame constantly, it will be better [4].

Heating value consists of highest heating value and lowest heating value. Highest heating value is resulted by perfect combustion of compact and liquid fuel. Lowest heating value is heating value minus the heat required for water [5].

\subsection{Briquette Characteritic Calculation}

Briquette characteritic calculation is to calculate combustion value.

Heating value:

$$
\mathrm{H}=\frac{W X T-E 1-E 2}{m}
$$

Note:

$\mathrm{H}=$ heating value of sample combustion (cal/gr)

$\mathrm{W}=$ energy equivalent $(\mathrm{cal} / \mathrm{c})$

$\mathrm{M}=$ sample mass (gr)

$\mathrm{T}=$ temperature rise $(\mathrm{c})(\mathrm{T} 2-\mathrm{T} 1)$

$\mathrm{E} 1=$ heat correction of sample (cal)

$\mathrm{E} 2$ = heat correction of hot wire (cal)

\subsection{Density}

Mass density is calculated by the following equation:

$$
\rho=\frac{m}{v}
$$




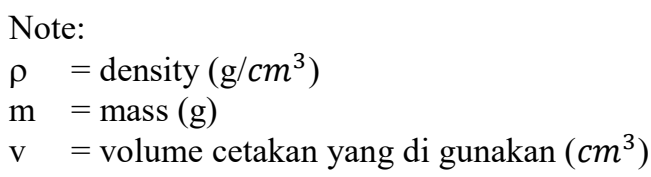

\subsection{Briquette Combustion Value}

Briquette combustion value is ratio between material mass and testing duration. The combustion value is calculated by using quotation:

$$
\mathrm{M}=\frac{m}{s}
$$

Note:

$\mathrm{M}=$ combustion value $(\mathrm{gr} / \mathrm{minute})$

$\mathrm{m}=$ test material mass (gr)

$\mathrm{s} \quad=$ waktu (minute)

\subsection{Ash Content Calculation}

Ash content is calculated by:

$\frac{F}{C} \times 100 \%$

Note:

$\mathrm{F}=$ residual weight

$\mathrm{C}$ = sample weight

This research uses experiment method. The equipments used in this study are: strainer 60 mesh, carbonized drum, chopper equipment for durin skin, briquette press, digital scale, thermocopel, oven, stop watch, pot of water, measuring cup, spatula, pestle, briquette stove, bomb calorie meter and lighter. The materials used are: durin skin and tapioca.

\subsection{Briquette}

The dried durian skin is chopped and mashed up, burnt in the drum in $3-4$ hours. Carbon particle produced is mashed up with 60 mesh and mixed up with tapioca adhesive respectively $6 \%$ (2.04gr), 9\% (3.06gr), 12\%(4.08gr), 15\% (5.1gr) of $34 \mathrm{gr}$ carbon particle of durian skin and mixed up with water, then the mixture is heated to become thick tapioca and starch glue. Mixing process between starch and particle carbon of durian skin is done referring to the above procedure. The mixed stuff is molded then dried in oven with temperature $150{ }^{0} \mathrm{C}$ during 20 minutes in order to reduce water content of the briquette. The briquette characteristic is tested in oven with $250{ }^{\circ} \mathrm{C}$.

\section{Result and Discussion}

\subsection{Heating Value Testing}

Heating value is tested by using calorimeter bomb to measure heat energy value of carbon powder with tapioca adhesive. 


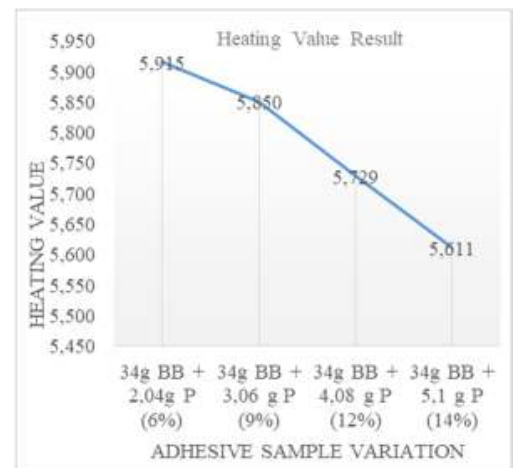

Fig. 1. Grafic of relationship between heating value and tapioca adhesive value.

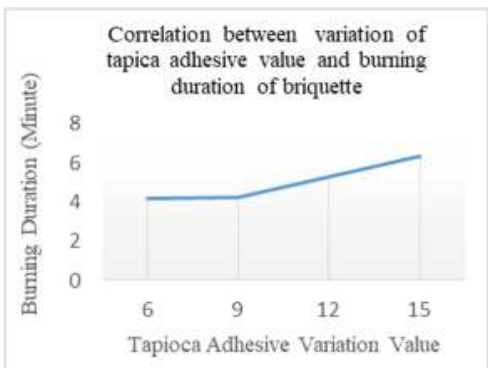

Fig. 2. shows that the more adhesive, the longer burning of briquette

Figure 1 above shows that the increasing of heating value is inversely proportional with the increasing of tapioca adhesive value of each briquette. The highest heating value is 5915 $\mathrm{cal} / \mathrm{gr}$ (34 gr carbon powder, $6 \%$ gluten) and the lowest heating value is $5611 \mathrm{cal} / \mathrm{gr}$ (34 gr carbon powder, $14 \%$ gluten).

Based on heating value testing in this study that the addition of tapioca adhesive of the briquette should be controlled because tapioca comes from vegatable which is sensitive on humidity, hence overused may increase water content and ash content that may make bed impact on heating value of briquette.

\subsection{Combustion Value Testing}

Heating value of durian skin briquette is tested to find out the appropriateness to be a fuel. The testing is by observing the phenomenon when the briquette put inside oven starting from volatile and burning the briquette to become ash.

Table 1. Relationship between variation of tapioca adhesive value on durian skin briquette and

\begin{tabular}{cccc}
\multicolumn{4}{c}{ burning at constant temperature of $250{ }^{\circ} \mathrm{C}$} \\
\hline $\begin{array}{c}\text { Adhesive } \\
\text { value } \\
(\%)\end{array}$ & $\begin{array}{c}\text { Burning } \\
\text { duration } \\
\text { (minute) }\end{array}$ & $\begin{array}{c}\text { Complete } \\
\text { burning } \\
\text { (minute) }\end{array}$ & $\begin{array}{c}\text { The highest } \\
\text { temperature } \\
\text { 0c }\end{array}$ \\
\hline 6 & 4.15 & 187.25 & 297 \\
9 & 4.23 & 190.11 & 297 \\
12 & 5.28 & 191.56 & 288 \\
15 & 6.29 & 193.13 & 288 \\
\hline
\end{tabular}




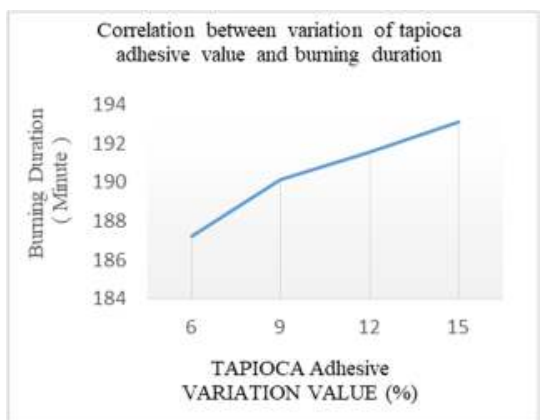

Fig. 3. Correlation between variation of tapioca adhesive value (\%) and burning duration (minute)

Table 2. Fuel distribution, length of burning and burning value.

\begin{tabular}{cccc}
\hline $\begin{array}{c}\text { Carbon fuel particle }+ \\
\text { adhesive }\end{array}$ & $\begin{array}{c}\text { Briquette } \\
\text { drying } \\
\text { (gr) }\end{array}$ & $\begin{array}{c}\text { Burning } \\
\text { duration } \\
\text { (minute) }\end{array}$ & $\begin{array}{c}\text { Burning } \\
\text { value } \\
\text { gr/min }\end{array}$ \\
\hline $34 \mathrm{~g} \mathrm{BB}+2.04 \mathrm{~g} \mathrm{P}(6 \%)$ & 49 & 187.25 & 0.2616 \\
$34 \mathrm{~g} \mathrm{BB}+3.06 \mathrm{~g} \mathrm{P}(9 \%)$ & 51 & 190.11 & 0.2682 \\
$34 \mathrm{~g} \mathrm{BB}+4.08 \mathrm{~g} \mathrm{P}(12 \%)$ & 52 & 191.56 & 0.2714 \\
$34 \mathrm{~g} \mathrm{BB}+5.1 \mathrm{~g} \mathrm{P}(15 \%)$ & 53 & 191.13 & 0.2744 \\
\hline
\end{tabular}

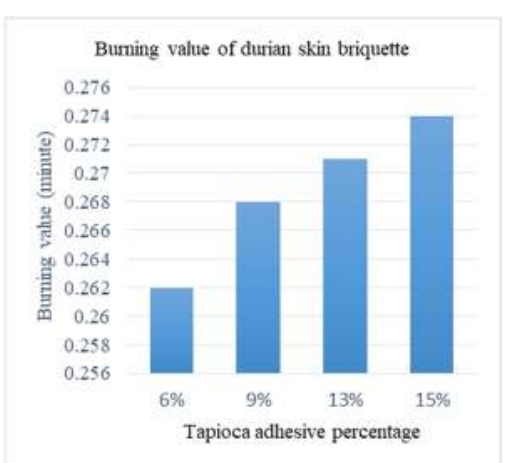

Fig. 4. Burning value of durian skin briquette

The experiment indicates that the lowest variation of tapioca adhesive $(6 \%)$ produces $0.2616 \mathrm{gr} /$ minute burning value, while the highest $(15 \%)$ produces $0.2744 \mathrm{gr} / \mathrm{minute}$. The adhesive material containing water will influence combustion.

\section{Conclusion}

Based on research, it can be concluded:

a. The increasing heating value is inversely proportional with percentage variation of tapioca adhesive of briquette. 
b. The highest heating value is $5915 \mathrm{cal} / \mathrm{gr}$ (34 gr carbon powder, $6 \%$ gluten) and the lowest heating value is $5611 \mathrm{cal} / \mathrm{gr}$ ( $34 \mathrm{gr}$ carbon powder, $14 \%$ gluten).

c. The more adhesive, the longer briquette burns.

d. The lowest variation of tapioca adhesive $(6 \%)$ produces $0.2616 \mathrm{gr} /$ minute burning value, while the highest (15\%) produces $0.2744 \mathrm{gr} /$ minute.

e. The adhesive material containing water will influence combustion.

\section{References}

[1] BAPPENAS, Lampiran Pidato Kenegaraan Presiden Republik Indonesia. Jakarta: Perum Percetakan Negara RI, 2017.

[2] M. R. Mubarok, "Pengaruh Variasi Perekat Tebu terhadap Karakteristik Briket Bioaranag dari Limbah Gergaji Kayu Mahoni," JTM, vol. 4, no. 1, pp. 1-7, 2015.

[3] E. H. Tjokrowisastro and Widodo, Teknik Pembakaran Dasar dan Bahan Bakar. Surabaya: Institut Teknologi Surabaya, 1990.

[4] S. Jamilatun, "Sifat-sifat Penyalaan dan Pembakaran Briket Biomassa, Briket Batu bara dan Arang Kayu," J. Rekayasa Proses, vol. 2, no. 2, 2008.

[5] N. H. Farel, Nilai Bahan Bakar Serabut dan Cangkang sebagai Bahan Bakar Ketel di Pabrik Kelapa Sawit. Medan: Teknik Mesin, FT USU Medan, 2006. 